\title{
Article \\ Applicability of Atmospheric Pressure Plasma Jet (APPJ) Discharge for the Reduction in Graphene Oxide Films and Synthesis of Carbon Nanomaterials
}

\author{
Sri Hari Bharath Vinoth Kumar ${ }^{1,2}$, Josefa Ibaceta-Jaña ${ }^{1}$, Natalia Maticuic ${ }^{2}{ }^{\mathbb{D}}$, Krystian Kowiorski ${ }^{3}$, \\ Matthias Zelt ${ }^{2}$, Ulrich Gernert ${ }^{4}$, Ludwika Lipińska ${ }^{3}{ }^{D}$, Bernd Szyszka ${ }^{1}$, Rutger Schlatmann ${ }^{2}$, Uwe Hartmann ${ }^{5}$ \\ and Ruslan Muydinov 1,2,*
}

Citation: Vinoth Kumar, S.H.B.; Ibaceta-Jaña, J.; Maticuic, N.; Kowiorski, K.; Zelt, M.; Gernert, U.; Lipińska, L.; Szyszka, B.; Schlatmann, R.; Hartmann, U.; et al. Applicability of Atmospheric Pressure Plasma Jet (APPJ) Discharge for the Reduction in Graphene Oxide Films and Synthesis of Carbon Nanomaterials. C 2021, 7,

71. https://doi.org/10.3390/ c7040071

Academic Editor: Gil Goncalves

Received: 16 September 2021

Accepted: 11 October 2021

Published: 14 October 2021

Publisher's Note: MDPI stays neutra with regard to jurisdictional claims in published maps and institutional affiliations.

Copyright: (C) 2021 by the authors Licensee MDPI, Basel, Switzerland. This article is an open access article distributed under the terms and conditions of the Creative Commons Attribution (CC BY) license (https:// creativecommons.org/licenses/by/ $4.0 /)$.
1 Institute for High-Frequency and Semiconductor-System Technologies, Technische Universität Berlin, Einsteinufer 25, 10587 Berlin, Germany; s.vinothkumar@tu-berlin.de (S.H.B.V.K.); josefa.ibaceta@gmail.com (J.I.-J.); bernd.szyszka@tu-berlin.de (B.S.)

2 PvcomB, Helmholtz-Zentrum Berlin für Materialien und Energie GmbH, Schwarzschildstraße 3, 12489 Berlin, Germany; natalia.maticiuc@helmholtz-berlin.de (N.M.); matthias.zelt@helmholtz-berlin.de (M.Z.); rutger.schlatmann@helmholtz-berlin.de (R.S.)

3 Graphene and Composites Research Group, Łukasiewicz Research Network-Institute of Microelectronics and Photonics, Aleja Lotników 32/46, 02-668 Warsaw, Poland; krystian.kowiorski@itme.edu.pl (K.K.); ludwika.lipinska@itme.edu.pl (L.L.)

4 Zentraleinrichtung Elektronenmikroskopie (ZELMI), Straße des 17. Juni 135, 10623 Berlin, Germany; ulrich.gernert@tu-berlin.de

5 Impellis GmbH \& Co., KG, Am Försterberg 12, 32805 Horn-Bad Meinberg, Germany; u.hartmann@impellis.de

* Correspondence: ruslan.muydinov@helmholtz-berlin.de

Abstract: Atmospheric pressure plasma jets (APPJ) are widely used in industry for surface cleaning and chemical modification. In the recent past, they have gained more scientific attention especially in the processing of carbon nanomaterials. In this work, a novel power generation technique was applied to realize the stable discharge in $\mathrm{N}_{2}\left(10 \mathrm{vol} . \% \mathrm{H}_{2}\right)$ forming gas in ambient conditions. This APPJ was used to reduce solution-processed graphene oxide (GO) thin films and the result was compared with an established and optimized reduction process in a low-pressure capacitively coupled (CCP) radiofrequency $(\mathrm{RF})$ hydrogen $\left(\mathrm{H}_{2}\right)$ plasma. The reduced $\mathrm{GO}(\mathrm{rGO})$ films were investigated by Raman spectroscopy and X-ray photoelectron spectroscopy (XPS). Effective deoxygenation of GO was observed after a quick $2 \mathrm{~s}$ treatment by AAPJ. Further deoxygenation at longer exposure times was found to proceed with the expense of GO-structure integrity. By adding acetylene gas into the same APPJ, carbon nanomaterials on various substrates were synthesized. The carbon materials were characterized by Raman spectroscopy, scanning electron microscopy (SEM), and energy-dispersive X-ray (EDX) analyses. Fullerene-like particles and graphitic carbon with short carbon nanotubes were detected on Si and Ag surfaces, respectively. We demonstrate that the APPJ tool has obvious potential for the versatile processing of carbon nanomaterials.

Keywords: atmospheric plasma; carbon nanomaterials; graphene oxide; plasma treatment

\section{Introduction}

Plasma techniques have been part of the material science and technology domain for the past several decades [1]. They are well integrated with today's research and industries in diverse applications due to high versatility, flexibility, and scalability. Recently, there has been a growing interest in the use of atmospheric plasma systems, and the APPJ systems, in particular [2-5]. The fundamentals of this technology have been reviewed in the literature [6-14]. APPJ can generate a high flux of various metastable but chemically very active species. Its use in ambient conditions allows setting up smaller, modular, and low-cost plasma sources for surface treatment. Since APPJs work with a gas flow, the 
ignition of plasma is spatially separated from the treatment surface [15]. This attribute has the following advantages: (i) the surface to be treated is safe from damage caused by arcs or discharge currents; and (ii) surfaces of objects with various shapes, geometries, and sizes can be treated. A limitation of the APPJs is the small area of a treatment restricted to a few millimeters. This limitation can be successfully overcome by scanning [16], using robotic arms [17], or an array of APPJs [18,19].

The applications of APPJs are numerous and can be broadly summarized into (i) surface modification; (ii) deposition of coatings, and (iii) biomedical applications $[2,3,5]$. This article relates to the former two themes. The crossover of the APPJ applications with the synthesis and processing of carbon nanomaterials is particularly interesting [20-23].

In the last four decades, the field of carbon materials has been extended with fullerenes, carbon dots, nanodiamonds, nanofibers, nanotubes, and graphene [24]. From these carbonallotropic forms, the growth and prospects of graphene have been compelling [25]. In our previous work, we highlighted the importance and scope of atmospheric plasma such as APPJ in the reduction in GO, which is one of the strategies to produce graphene films [26].

There is also an emerging interest in the production of free-standing graphene (gasphase synthesized graphene, GSG) at atmospheric pressure. The GSG is formed in the afterglow region of plasma discharge where nucleation and growth take place $[27,28]$. Microwave (MW)-induced plasma is predominantly utilized for such synthesis [29-31]. Jašek et al. [31] deposited GSG layers from ethanol vapors in argon in this way. Such plasma heated the $\mathrm{Si} / \mathrm{SiO}_{2}$ substrate to $\sim 650-1150{ }^{\circ} \mathrm{C}$, depending on plasma conditions. The results are commendable, but the approach needs further development to operate at lower temperatures suited for sensitive (e.g., flexible) substrates. Researchers have also synthesized GSG using high-power APPJ (30-40 kW power, 300-400 A) fixed and enclosed in a reactor with graphitic walls [24,32-34]. The reactor was further enclosed in a vacuum chamber with helium or argon feed-through. As a graphene forming admixture, propane/butane or methane, or acetylene were used. A drastic cooling of the discharge flow resulted in the formation of a solid form of carbon. Crumbled graphene sheets of various sizes (up to a few hundred nanometers) with the number of layers in the range of 1-10 have been obtained. Although this technique is attractive, some of the downsides are [32-34]: (i) a very high power consumption; (ii) the necessity of special auxiliary systems including a vacuum chamber with cooling; and (iii) the crumbled nature of graphene, and the need for a post-synthesis solution process to realize particular applications such as transparent conductive layers, sensors, and other functional coatings.

Motivated by the need for an atmospheric plasma system to be able to deposit graphene films in ambient conditions, we developed a low-power APPJ system. Although the glowing gas jet is named "Plasma" in the literature, it is not strictly correct in our case since most gas species are not ionized but excited. Our free jet system provides a lower temperature of neutrals as compared to the known APPJs. Due to the discontinuity of power coupling, not all the flowing gas is electrically affected. The potential applications of this system are demonstrated for: (i) reduction in GO films and (ii) deposition of carbon nanomaterials on various substrates (described in Sections 3.1 and 3.2, respectively).

\section{Materials and Methods}

As substrates, an Eagle $X G^{\circledR}$ (Corning Inc., Corning, NY, USA) glass of $1.1 \mathrm{~mm}$ thickness and p-type (100)-oriented $\mathrm{Si}$ (Microchemicals $\mathrm{GmbH}$, Ulm, Germany) were used. Before deposition, the substrates were sonicated at $50{ }^{\circ} \mathrm{C}$ in organic solvents (acetone, isopropanol) and washed in a glass-washer using a universal detergent $\left(\right.$ Hellmanex $\left.^{\circledR}\right)$ and deionized water.

All GO samples were prepared only on Si substrates. The aqueous dispersion of GO was prepared with flakes obtained from graphite by a modified Hummers method. Further experimental details are described in the literature [35-37]. The $2 \mathrm{mg} / \mathrm{mL}$ GO dispersion in deionized water (DI) (flake size 1-100 $\mu \mathrm{m}$ ) was spin-coated at $2000 \mathrm{rpm}$ for $30 \mathrm{~s}$ on $1.5 \times$ $1.5 \mathrm{~cm}^{2}$ substrates. The films were dried at room temperature (RT) overnight in a $\mathrm{N}_{2}$-filled 
glovebox. As found by SEM and confirmed by ellipsometry these films had a thickness of $\sim 20 \mathrm{~nm}$ and a multilayered porous microstructure.

The commercial PlasmaJet ${ }^{\circledR}$ (Raantec GmbH \& Co., KG, Borgholzhausen, Germany) system was specially redesigned for our purposes. Since molecular $\mathrm{H}_{2}$ inhibits plasma generation, the electronic components of the power generator have been modified. Power generation was also optimized for the gas mixtures used and thus operated at an MFinduced $(31.8 \mathrm{kHz})$ direct current $(\mathrm{DC})$ power $(480 \mathrm{~W})$. The free jet nozzle was constructed to provide a vortex-like flow of gas. The nozzle head design details are available in the patent DE 19532412 C 2. The internal glowing chamber was equipped with a ringelectrode, which also worked as an outcoupling window. Another electrode was placed in the middle of the chamber on the back side. Fine-tuning of the power generation provided the following gas excitation conditions:

- $\quad$ high enough excitation degree;

- gas leaving the nozzle electrically unchanged;

- $\quad$ gas species remaining excited outside the nozzle;

- the relaxation of excited species producing energy in the infrared (IR) range.

So far, no detailed optical emission spectroscopy (OES) analysis of our free jets has been performed, however, it is planned for future work. The GO-reduction treatment was performed in a flow $(30 \mathrm{~L} / \mathrm{h})$ of forming gas $\left(10 \mathrm{vol} . \% \mathrm{H}_{2}\right.$ in $\left.\mathrm{N}_{2}\right)$. The substrate to nozzle distance was $8 \mathrm{~mm}$, and the plasma irradiation time was varied at $2 \mathrm{~s}, 5 \mathrm{~s}$, and $10 \mathrm{~s}$. To avoid rGO reoxidation in air, the freshly treated surfaces were exposed to the same flow for $20 \mathrm{~s}$ after the plasma power supply was turned off. For all treatments/deposition with the APPJ, no external sample heating was used. The GO reduced with APPJ in ambient conditions was compared to rGO reduced in a $\mathrm{H}_{2}$-plasma environment. For this, an $\mathrm{RF}-$ plasma treatment was carried out in the AKT 1600 system (Applied Materials, Santa Clara, CA, USA) described elsewhere [38]. After comprehensive optimization where RF-power, temperature, and treatment time were varied, the conditions chosen were: $100 \mathrm{~W}$ RF power, $30 \mathrm{~s}$ treatment, and $200{ }^{\circ} \mathrm{C}$ substrate temperature. The heating was performed in hydrogen for $10 \mathrm{~min}$ and the cooling in the load lock chamber for $5 \mathrm{~min}$ under vacuum. A pure $\mathrm{H}_{2}$ (99.9999\%) environment at a process pressure of $133.3 \mathrm{~Pa}$ was used during the treatment.

The in-house prepared RF-sputtered Corning ${ }^{\circledR}$-glass $/ \sim 20 \mathrm{~nm} i-\mathrm{ZnO} / \sim 20 \mathrm{~nm} \mathrm{Ag}$ film stack (referred to as $\mathrm{ZnO} / \mathrm{Ag}$ from here onwards) and $\mathrm{Si}$ were used as substrates for carbon APPJ deposition. A Corning ${ }^{\circledR}$-glass of size $2.5 \times 2.5 \mathrm{~cm}^{2}$ was used for the sputtering of $\mathrm{ZnO} / \mathrm{Ag}$. The sputtering process for $\mathrm{i}-\mathrm{ZnO}$ was described in previous work [39]. Silver films were deposited in the DC magnetron sputtering system A600V7 (Leybold Optics Dresden $\mathrm{GmbH}$, Dresden, Germany) at a 75-mm target-to-substrate distance. The base pressure was $5.37 \times 10^{-4} \mathrm{~Pa}$, the process was performed in $\operatorname{Ar}(99.999 \%)$ at a pressure of $5.16 \times 10^{-1} \mathrm{~Pa}$. The power density was $1.33 \mathrm{~W} / \mathrm{cm}^{2}$, no intentional heating of a substrate was used. The substrate holder oscillated with a $4.8 \mathrm{~m} / \mathrm{min}$ speed. No special pretreatment such as etching of $\mathrm{SiO}_{x}$ from silicon wafer was applied before carbon depositions. The metallic silver film grew (111)-textured on (0002)-ZnO seed layer (Figure S1a), which was in good agreement with the literature [40]. Herewith, the Ag-film was not textured in-plane (Figure S1). For carbon synthesis, the APPJ discharge contained a mixture of $\mathrm{C}_{2} \mathrm{H}_{2}$ (feedstock gas, $0.5 \mathrm{~L} / \mathrm{h}$ flow) and forming gas (10 vol.\% $\mathrm{H}_{2}$ in $\mathrm{N}_{2}, 30 \mathrm{~L} / \mathrm{h}$ flow). The substrate to nozzle distance varied between 3 and $6 \mathrm{~mm}$. The $1 \times 1 \mathrm{~cm}^{2}$ cut $\mathrm{ZnO} / \mathrm{Ag}$ films, optimized based on resistance measurements in Van der Pauw geometry (Rsh $\approx 10 \Omega$ ), were chosen for the carbon depositions. The photographs of the APPJ working with two considered gas mixtures are shown in Figure S2. All freshly treated or deposited samples were immediately packed into vacuum-sealed plastic bags for transport or storage until the next processing step or analysis.

Scanning electron microscopy (SEM) and energy dispersive X-ray analyses (EDX) were performed on a Hitachi SU8030 SEM (Tokyo, Japan) with a CFEG (cold field emitter gun) and EDX analyzer EDAX TEAM system with a $30 \mathrm{~mm}^{2}$ Octane SDD (silicon drift detector). XRD measurements were completed on the Bruker Discovery D8 (Karlsruhe, Germany) 
system using $\mathrm{Cu} \mathrm{K} \mathrm{K}_{\alpha}$ radiation and the high-resolution mode of the 1D-LYNXEYE XE-T detector. For the acquisition of the pole figure, Polycap optics were installed.

XPS measurements were carried out using nonmonochromatic $\mathrm{Mg} \mathrm{K} \mathrm{K}_{\alpha}$ radiation $(1254 \mathrm{eV})$ [41]. The raw XPS spectra of the various GO were fit using the XPSPEAK 4.1 software by non-linear least-squares fittings with a Gaussian/Lorentzian ratio of 80:20 [42]. Micro-Raman spectroscopy was performed in a high-resolution Horiba Jobin Yvon LabRAM HR800 (Bensheim, Germany) spectrometer. Samples deposited with the $\mathrm{C}_{2} \mathrm{H}_{2}$ plasma on $\mathrm{Si}$ and $\mathrm{ZnO} / \mathrm{Ag}$ substrates were measured with an excitation source of $633 \mathrm{~nm}$ and a power of $2.49 \mathrm{~mW}$. The GO and rGO (reduced with APPJ) on Si were measured with an excitation wavelength of $532 \mathrm{~nm}$ with a power of $2.60 \mathrm{~mW}$, while the set of GO and rGO prepared with the $\mathrm{RF}_{2}$-plasma was measured with $633 \mathrm{~nm}$ excitation source and power of $5 \mathrm{~mW}$. Different Raman excitation wavelengths used during the investigation were solely due to lab availability. The acquisition parameters were grating of 600 lines per millimeter, an aperture of $400 \mu \mathrm{m}$, and an objective of $100 \times$. The Raman spectra were fit using Fityk software (version 1.3.1).

\section{Results and Discussion}

\subsection{Reduction in GO}

The fitted Raman spectra for the GO and various rGO are presented in Figure 1 where a combination of three pseudo-Voigt and two Gaussian functions were used [43]. The fit data such as peak centers, intensity, and full width at half maximum (FWHM) have been summarized in the supplementary information, Table S1. In pure graphite, the peak at $\sim 1580 \mathrm{~cm}^{-1}$ corresponded to the G-band arising from the $E_{2 \mathrm{~g}}$-symmetry of the carbon lattice [44]. In the case of $\mathrm{GO} / \mathrm{rGO}$, this peak either blueshifted or redshifted based on the excitation laser frequency. The spectra also exhibited peaks at $\sim 1350 \mathrm{~cm}^{-1}$ (D-band) and $\sim 1620 \mathrm{~cm}^{-1}$ ( $\mathrm{D}^{\prime}$-band) corresponding to the disorder-induced phonon mode due to the finite size of crystals and defects [45]. The $\mathrm{D}^{\prime}$-band has also been attributed to vacancy defects in pentagonal and octagonal rings in the literature [46]. The shoulder at $\sim 1200 \mathrm{~cm}^{-1}$ was the $\mathrm{D}^{*}$-band also arising from disordered graphitic lattice provided by the $\mathrm{sp}^{2}-\mathrm{sp}^{3}$ bonds at the edges of the network [44]. The attribution of the $\mathrm{D}^{\prime \prime}$-band at $\sim 1480 \mathrm{~cm}^{-1}$ was ambiguous [43] as it has been assigned to (i) phonon density of states in finite-sized crystals [47], (ii) amorphous lattices, since the intensity of the $\mathrm{D}^{\prime \prime}$ band was found to decrease with an increase in crystallinity [48], (iii) amorphous $\mathrm{sp}^{2}$-bonded forms, including functionalized small molecules [44,49], and (iv) a double resonance process with the iTO phonon branch [50].

In the literature, the peak at $\sim 1447 \mathrm{~cm}^{-1}$ has been attributed to either the scissoring mode of $-\mathrm{CH}_{2}[51-53]$ or the $\mathrm{C}=\mathrm{C}$ ring stretching in thiophene (containing nitrogen) $[54,55]$. Moreover, a peak $1450 \mathrm{~cm}^{-1}$ in nanocrystalline diamond is said to arise from the sum modes of $\mathrm{sp}^{2} \mathrm{C}=\mathrm{C}$ and $\mathrm{C}-\mathrm{H}$ vibrations of trans-polyacetylene type segments at grain boundaries $[42,56]$. In the case of the rGO samples here, this peak is likely to be from the mode of $-\mathrm{CH}_{2}$ as it was confirmed with XPS analysis that foreign atoms were not incorporated into the rGO. Therefore, the emergence of these peaks indicated that the sample structure deviated from the typical GO structure [57]. With a $10 \mathrm{~s}$ APPJ-reduction, the structure of rGO seemed to further deviate from the $5 \mathrm{~s}$ APPJ-reduced sample (see supplementary information, Figure S3). The overtone bands (2D or $\mathrm{G}^{\prime}, \mathrm{D}+\mathrm{G}$, and $2 \mathrm{G}[58,59]$ ) were found in the region $2500-3300 \mathrm{~cm}^{-1}$ for the GO and they decreased in intensity with increasing free-jet exposure time (supplementary information, Figure S3). This can be attributed to the formation of defects and diminishing $\mathrm{sp}^{2}-\mathrm{C}$ domains [59-61]. 

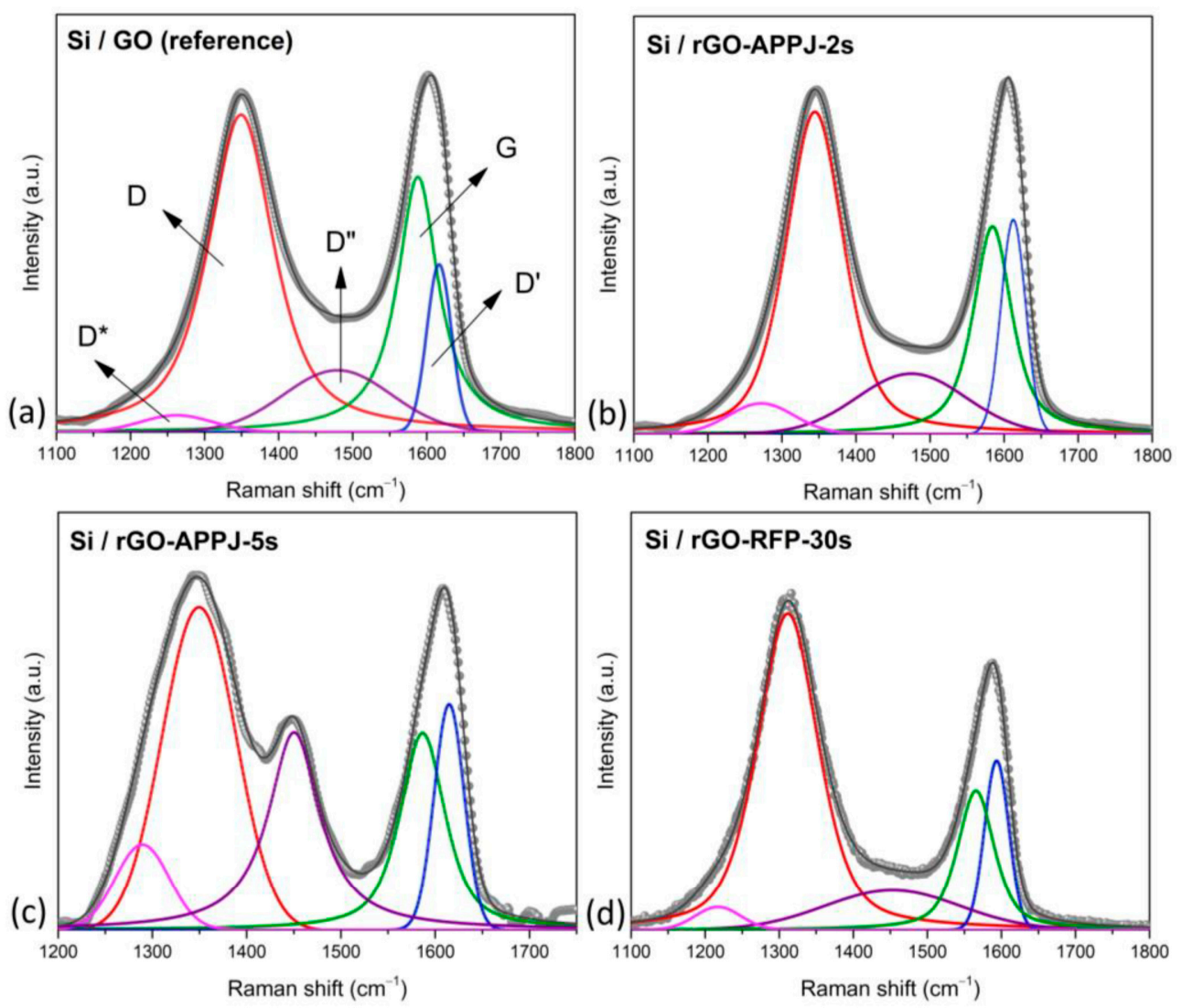

Figure 1. Fitted Raman spectra of GO (a), 2 s APPJ reduced GO (b), 5 s APPJ reduced GO (c), and 30 s RF plasma reduced GO (d) on Si substrates.

The XPS survey of the various GO is shown in the supplementary information, Figure S4. As expected, peaks arising from carbon $(\sim 284 \mathrm{eV})$ and oxygen $(\sim 531 \mathrm{eV})$ were observed along with silicon (99-169 eV) from the substrate. Interestingly, nitrogen signals were not found in the APPJ-processed GO samples, which were exposed to plasma containing nitrogen species. This suggested that nitrogen doping did not occur for the rGO. For samples treated with APPJ for 5 and $10 \mathrm{~s}$, traces of iron (Fe) were found originating from the sample holder (supplementary information, Figure S4). Figure 2 presents the XPS core levels of the GO and various rGO. The chemical components identified from the spectra were $\mathrm{sp}^{2}$-hybridized carbon $\left(\mathrm{sp}^{2}-\mathrm{C}\right), \mathrm{sp}^{3}$-hybridized carbon $\left(\mathrm{sp}^{3}-\mathrm{C}, \mathrm{C}-\right.$ $\mathrm{C} / \mathrm{C}-\mathrm{H})$, hydroxyl $-(\mathrm{C}-\mathrm{OH})$, epoxide $-(\mathrm{C}-\mathrm{O}-\mathrm{C})$, carbonyl $-(\mathrm{C}=\mathrm{O})$, and carboxyl $-(\mathrm{CO}(\mathrm{OH}))$ groups, respectively $[60,62-67]$. For the sample rGO-APPJ-5s, a feature at binding energy $>290 \mathrm{eV}$ was distinctively observed. In the literature, this has been assigned to energy losses due to $\pi-\pi^{*}$ excitations, which is typical for carbonaceous systems with delocalized $\pi$-electrons [68], as well as to carbon atoms bonded to metals [69].

The increasing trend of the $\mathrm{I}_{\mathrm{D}} /\left(\mathrm{I}_{\mathrm{G}}+\mathrm{I}_{\mathrm{D}^{\prime}}\right)$ ratio from Raman spectroscopy was an indicator of deoxygenation in GO (Table 1). The increasing ratio arose from the increasing quantity of disorder, which in turn was associated with the appearance of new $\mathrm{sp}^{2}-\mathrm{C}$ domains with the loss of carbon-oxygen bonds [70]. The loss of oxygen bonds was also verified from the XPS quantification of the components' fit for the C1s spectra. The crystallite size was calculated from the areas of the D band and G band in Raman spectra using the Tuinstra and Koenig relation [71-73]. The calculated average crystallite size (La) for GO was $10.8 \mathrm{~nm}$ when the Raman signals were measured with a 532-nm laser. It reduced to $9.6 \mathrm{~nm}$ and $8.4 \mathrm{~nm}$ when the GO was reduced with APPJ plasma for 2 and $5 \mathrm{~s}$, respectively. In the case of RF plasma treatment, the crystallite was reduced to $9.2 \mathrm{~nm}$ from $10.2 \mathrm{~nm}$ (Raman signals recorded with $633 \mathrm{~nm}$ laser). The average distance between the defects reduced to $7.9 \mathrm{~nm}$ and $7.4 \mathrm{~nm}$ from $8.4 \mathrm{~nm}$ for an APPJ treatment time of 2 and $5 \mathrm{~s}$, 
respectively. With the $30 \mathrm{~s}$ RF plasma treatment, the distance between defects reduced to $7.9 \mathrm{~nm}$ from $8.2 \mathrm{~nm}$. This suggests that with plasma irradiation defects were created in the rGO which is already well established in the literature. The $30 \mathrm{~s} \mathrm{RF}$ plasma irradiation produced similar defects as the $2 \mathrm{~s}$ APPJ exposure, indicating that the APPJ had higher energetic plasma species than the RF-plasma used.
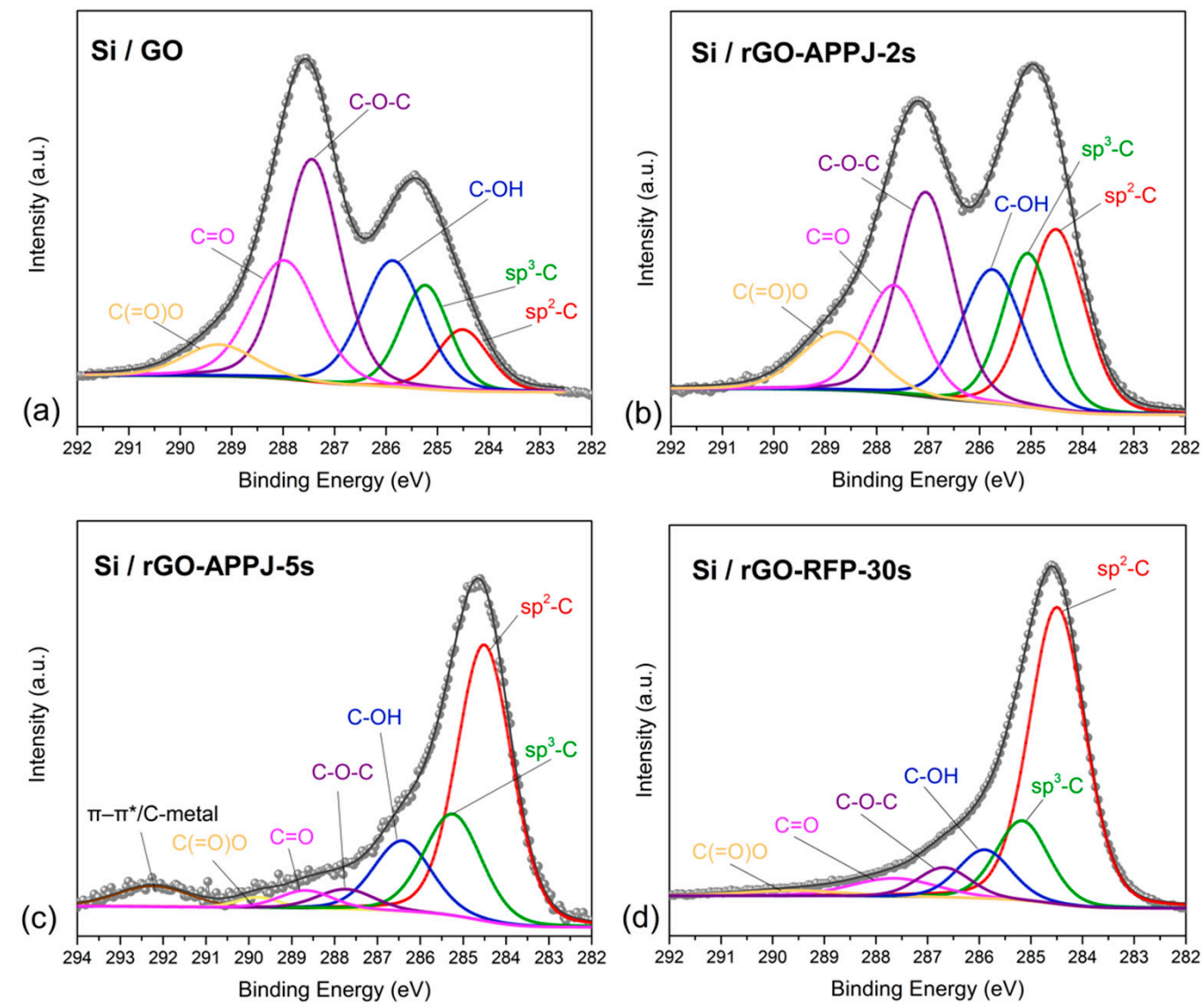

Figure 2. High-resolution XPS spectra in the C1s region for GO (a), $2 \mathrm{~s}$ APPJ reduced GO (b), $5 \mathrm{~s}$ APPJ reduced GO (c), and 30 s RF plasma reduced GO (d) on Si substrates.

Table 1. The calculated values of $\mathrm{I}_{\mathrm{D}} /\left(\mathrm{I}_{\mathrm{G}}+\mathrm{I}_{\mathrm{D}^{\prime}}\right)$, the average crystallite size $\left(\mathrm{L}_{\mathrm{a}}\right)$, and the average distance between defects $\left(\mathrm{L}_{\mathrm{D}}\right)$ for GO and various rGO from Raman spectroscopy (Figure 1 and Table S1). rGO-RF-30s and its reference GO sample (indicated by + ) were measured with $633 \mathrm{~nm}$ laser excitation, while the remaining samples were measured with $532 \mathrm{~nm}$ laser excitation. Quantification (area distribution in \%) of the components fitted in the C1s spectra (Figure 2). For the rGO-APPJ-5s sample, a contribution of 5.2\% from the feature at binding energy $>290 \mathrm{eV}$ (discussed earlier) was not tabulated.

\begin{tabular}{|c|c|c|c|c|c|c|c|c|c|}
\hline \multirow{2}{*}{ Sample } & \multicolumn{3}{|c|}{ Raman Analysis } & \multicolumn{6}{|c|}{ XPS Quantification Analysis } \\
\hline & $\mathrm{I}_{\mathrm{D}} /\left(\mathrm{I}_{\mathrm{G}}+\mathrm{I}_{\mathrm{D}^{\prime}}\right)$ & $\mathrm{L}_{\mathrm{a}}(\mathrm{nm})$ & $\mathrm{L}_{\mathrm{D}}(\mathrm{nm})$ & $\mathrm{sp}^{2}-\mathrm{C}$ & $s p^{3}-C$ & $\mathrm{C}-\mathrm{OH}$ & $\mathrm{C}-\mathrm{O}-\mathrm{C}$ & $\mathrm{C}=\mathrm{O}$ & $\mathrm{C}(\mathrm{O}) \mathrm{OH}$ \\
\hline $\mathrm{GO}$ & 0.75 & 10.8 & 8.4 & 8.2 & 12.9 & 20 & 32.8 & 20.3 & 5.8 \\
\hline rGO-APPJ-2s & 0.76 & 9.6 & 7.9 & 21.3 & 16.1 & 17.1 & 23.8 & 12.8 & 8.9 \\
\hline rGO-APPJ-5s & 0.79 & 8.4 & 7.4 & 52.0 & 20.1 & 14.0 & 3.9 & 3.3 & 1.5 \\
\hline $\mathrm{GO}^{+}$ & 1.06 & 10.2 & 8.2 & 41.7 & 23.1 & 9.1 & 7.7 & 5.6 & 9.2 \\
\hline rGO-RF-30s ${ }^{\dagger}$ & 1.08 & 9.7 & 7.9 & 61.3 & 15.4 & 9.5 & 5.8 & 5.8 & 2.1 \\
\hline
\end{tabular}

The hydrogen RF plasma typically constitutes free electrons, neutrals (molecular $\mathrm{H}_{2}$, atomic $\mathrm{H}$ ), and charged ions $\left(\mathrm{H}^{-}, \mathrm{H}^{+}, \mathrm{H}_{2}{ }^{+}\right.$, and $\left.\mathrm{H}_{3}{ }^{+}\right)$[74]. The plasma composition is relatively stable and homogeneous stipulating nearly equilibrium conditions for chemical interactions. At the same time, the electrodeless RF-coupling powers the high temperature of neutrals. Hydrogen-containing APPJ reveals mostly nitrogen second positive system 
bands and $\mathrm{NH}$ [75]; typical species from $\mathrm{N}_{2}$ discharge are $\mathrm{N}, \mathrm{NO} \bullet, \mathrm{OH} \bullet, \mathrm{N}_{2}, \mathrm{~N}_{2}{ }^{+}$, and $\mathrm{CN}$ [76]. As pointed above, the gas in our free jet was expected to be negligibly ionized, especially at the distance of the surface reaction event. In GO, the carbon bonded to oxygen accounted for nearly $79 \%$ of the total carbon bonds. In the case of carbon-to-carbon bonds (Table 1), the fraction of $\mathrm{sp}^{3}$-hybridized content $(12.9 \%)$ was found to be higher than $\mathrm{sp}^{2}$ hybridized bonds (8.2\%). Even with a short $2 \mathrm{~s}$ APPJ-treatment, the oxygen-containing group loss was observed, and the amount of $\mathrm{sp}^{2}$-carbon content $(\sim 21 \%)$ increased relative to $\mathrm{sp}^{3}$-carbon $(\sim 16 \%)$. With a $5 \mathrm{~s}$ APPJ-treatment, the net oxygen-containing group fraction reduced to $\sim 23 \%$, and the restoration of $\mathrm{sp}^{2}-\mathrm{C}$ increased to $52 \%$. To compare, the optimized hydrogen RF-plasma reduced net oxygen-content in the GO film down to $\sim 24 \%$, while the $\mathrm{sp}^{2}-\mathrm{C}$ content increased to $\sim 61 \%$. Compared to the $5 \mathrm{~s}$ APPJ-treatment, the RF plasma treatment yielded a lower content of $\mathrm{C}-\mathrm{OH}$ and $\mathrm{O}=\mathrm{C}-\mathrm{OH}$ groups, whereas the APPJtreatment yielded a lower content of $\mathrm{C}-\mathrm{O}-\mathrm{C}$ and $\mathrm{C}=\mathrm{O}$ groups.

\subsection{Synthesis of Carbon Nanomaterials}

\subsubsection{Deposition on $\mathrm{ZnO} / \mathrm{Ag}$ Substrates}

It is known, that the (111)-facet of fcc-metals such as $\mathrm{Cu}$ and Ni serve as a template for the honeycomb carbon network $[77,78]$. The lattice mismatch with graphene in these cases exceeds $-10 \%$. According to our estimation, the 111-Ag lattice would have less than $+2 \%$ mismatch at normal conditions. That is why we have chosen it as a substrate, which is a standard for low-emissivity coating technology. Figure 3 presents the Raman spectra of carbon deposited on $\mathrm{ZnO} / \mathrm{Ag}$ substrates, and they were fitted with a combination of Lorentzian and Gaussian (only for D3 band) functions [44]. The parameters extracted from the fitted peak are summarized in the supplementary information, Table S2 and the broad Raman spectrum is presented in the supplementary information, Figure S5. In the $250-750 \mathrm{~cm}^{-1}$ region (Figure S5), several peaks and bands were strongly observed for samples deposited at a distance of $3 \mathrm{~mm}$ for $1 \mathrm{~s}$ (and weakly when deposited at a distance of $6 \mathrm{~mm}$ from the substrate). These features are attributed to the underlying glass substrate [79], $\mathrm{ZnO}$ [80], and $\mathrm{Ag}-\mathrm{O}$ [81]. Except for the sample deposited at $3 \mathrm{~mm}$ and $1 \mathrm{~s}$, the samples portrayed well-separated D and $\mathrm{G}$ bands suggesting relatively low amorphous content or high crystalline (graphitic) content [82].

The $\mathrm{G}$ band split into $\mathrm{G}^{-}$band and $\mathrm{G}^{+}$band (Figure 3), which is usually observed in carbon nanotubes (CNT) as a result of curvature [83]. This splitting has also been observed when graphene sheets are strained [84], wrinkled [85], or folded and scrolled [86].

A weak 2D band $\left(2700 \mathrm{~cm}^{-1}\right)$ was detected in all the samples (supplementary information, Figure S5). The 2D band is a well-known characteristic feature of all the $\mathrm{sp}^{2}-\mathrm{C}$ based materials [87-89]. The films deposited for $2 \mathrm{~s}$ revealed relatively prominent 2D peaks, as well as the $G+D$ band $\left(\sim 2900 \mathrm{~cm}^{-1}\right)$ (supplementary information, Figure S5). The existence of these features is assessed as a lower disorder in the films [60]. The D3 band $\left(\sim 1500 \mathrm{~cm}^{-1}\right)$ is assigned to the presence of amorphous carbon [44,90]. The D4 band $\left(\sim 1200 \mathrm{~cm}^{-1}\right)$ is assigned to the aliphatic compounds grafted on the disordered carbon network [90,91] or defective graphite [90,92]. In some samples (Figure $3 b, c)$, a weaker $\mathrm{D}^{\prime \prime}$ band $\left(1076-1095 \mathrm{~cm}^{-1}\right)$ is also additionally observed originating from defects $[90,92,93]$.

The estimated crystallite size $\left(\mathrm{L}_{\mathrm{a}}\right)$ from Raman spectroscopy were $8.7 \mathrm{~nm}, 10.2 \mathrm{~nm}$, $10 \mathrm{~nm}$, and $11.6 \mathrm{~nm}$ for the samples Ag-C-D3-1S, Ag-C-D3-2S, Ag-C-D6-1S, and Ag-CD6-2S, respectively [71-73]. Similarly, these samples had an estimated defect between the point defects $\left(L_{D}\right)$ as $7.5 \mathrm{~nm}, 8.2 \mathrm{~nm}, 8 \mathrm{~nm}$, and $8.7 \mathrm{~nm}$, in the same order. The SEM images (supplementary information, Figures S6 and S7) evidenced several microstructural changes as compared to the initial silver surface (Figure S7a,b). Silver recrystallized and probably shrank, which led to a formation of pores (dark regions ranged in size from a few 10s of nm to $\sim 100 \mathrm{~nm}$ ). Point EDX analysis of the largest dark areas revealed greater $\mathrm{Zn}$ and lesser Ag-content as compared to the flat particle-free areas. These relatively homogeneous areas were notably smoother in treated samples than the surface of the initial silver film. One can also distinguish in a few places an increase in the size of Ag grains, but the surface 
appears to be coated with carbon. Nano needle-like structures (or short nanotubes) were also observed, whose diameter was $\sim 50 \mathrm{~nm}$, and length was in the range of $100 \mathrm{~s} \mathrm{of} \mathrm{nm}$. Similar to the pores, the number of short nanotubes also decreased at a higher nozzle distance and longer deposition time. Bright dots observed in the SEM images with higher magnification represent silver particles according to EDX.

(a)
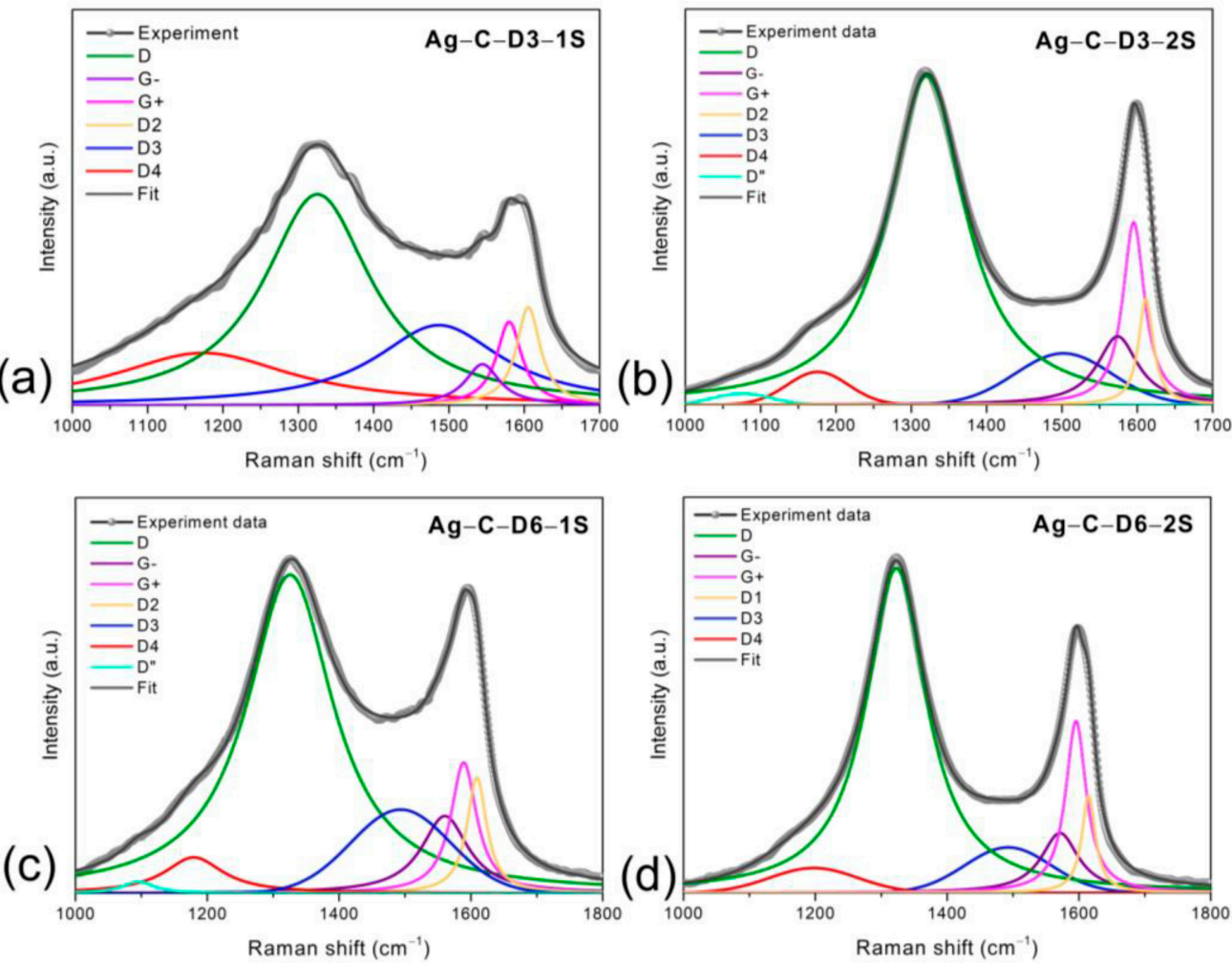

Figure 3. Fitted Raman spectra for carbon deposited on $\mathrm{ZnO} / \mathrm{Ag}$ substrates at various nozzle-tosubstrate distances and durations: (a) at $3 \mathrm{~mm}$ for $1 \mathrm{~s},(\mathbf{b})$ at $3 \mathrm{~mm}$ for $2 \mathrm{~s}$, (c) at $6 \mathrm{~mm}$ for $1 \mathrm{~s}$, and (d) at $6 \mathrm{~mm}$ for $2 \mathrm{~s}$.

\subsubsection{Deposition on Si Substrates}

It is known that native Si-wafers are oxidized from the surface. This oxide is very smooth and dense but not crystalline. We took this substrate for the next experiments to discard the template impact of a substrate. The dynamic linearly oscillating deposition was undertaken at the nozzle-to-substrate distance of $6 \mathrm{~mm}$ to avoid overheating the substrate. The Raman spectra of the carbon deposited on Si substrates are shown in Figure 4 and the peak assignments are summarized in Table 2. The carbon deposited for 2-20 s displayed a similar spectral feature, and their interpretation was not straightforward. Some prominently observed features in the spectra were the bands in the range 1050-1100 $\mathrm{cm}^{-1}$ coinciding with $C-C$ stretching observed in hydrocarbon chains $[94,95]$ and several peaks up to $1450 \mathrm{~cm}^{-1}$ which are observed in C60/C70-fullerene materials (see Table 2) [96,97].

It should be also noted that the region $1100-1150 \mathrm{~cm}^{-1}$ and $1430-1470 \mathrm{~cm}^{-1}$ were related to the trans-polyacetylene segments at the grain boundaries [98]. The peaks $\sim 1060 \mathrm{~cm}^{-1}$ and $\sim 1180 \mathrm{~cm}^{-1}$ also have been reported for the nanocrystalline phase of carbon [99]. The $\mathrm{sp}^{2}-\mathrm{C}$ phase or the $\mathrm{G}$ band $\left(1560 \mathrm{~cm}^{-1}\right)$ from the in-plane stretching mode of carbon is observed only when the deposition time is high at $30 \mathrm{~s}$ [100,101]. The carbon with the broad G and D bands indicates the existence of an amorphous structure [82]. However, features of the fullerene-like structure were also superimposed into the dominant broad $G$ and $D$ bands. This suggests a possible composite structure of fullerene-like matter and amorphous films. The SEM images of the carbon samples are presented in the supplementary information, Figure S8. For up to a deposition time of $20 \mathrm{~s}$, the surface 
coverage was nonuniform and low with clusters of spherical particles. In the sample deposited for $30 \mathrm{~s}$, spherical particles of various sizes (several $10 \mathrm{~s}$ of $\mathrm{nm}$ ) were observed with some in aggregated form. These aggregates (supplementary information, Figure S5d) were comparable to onion-like fullerene/nanocarbon (fullerenoid) structures reported in the literature [20,102-105].

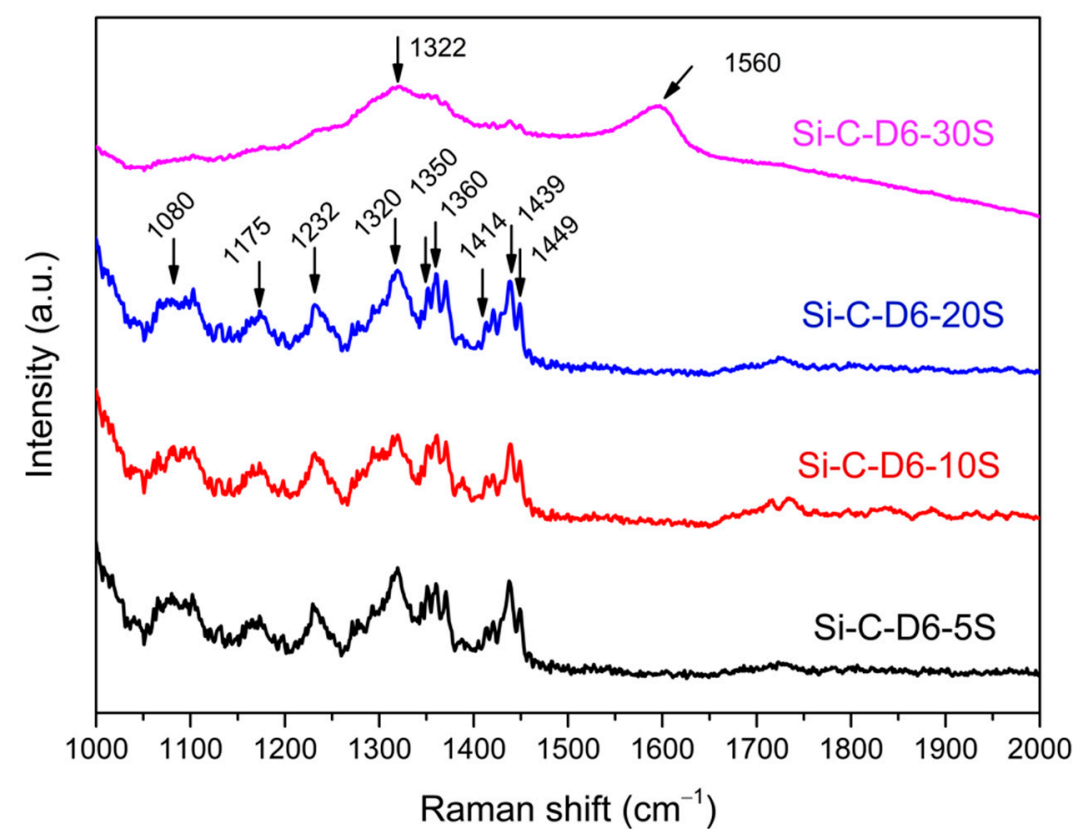

Figure 4. Raman spectra of the carbon deposited on Si substrates for various time and nozzle distances.

The idea of using acetylene to synthesize or to deposit the $\mathrm{sp}^{2}$-carbon network was based on the corresponding catalytic synthesis of benzene. This can proceed for instance via adsorption on Pd-surface [106], or be promoted by transition metals, which are known to catalyze the so-called [2+2+2]-polymerization [107]. Silicon atoms may also form intermediates driving the polymerization process [108]. In combination with admixtures increasing the Lewis acid character of the promoter (e.g., $\mathrm{Si}^{+4}$ ), the reaction in question can proceed at much lower temperatures than the established $500-600{ }^{\circ} \mathrm{C}$ [109]. The entire mechanism of polymerization in plasma from a single carbon atom to fullerenes was proposed and described in detail elsewhere [110]. In the case of a plasma torch process at atmospheric pressure, the formation of a similar carbon-onion-like structure passes through dissociation, nucleation, and agglomeration events in the carbon feedstock gas [102]. The spherical agglomerates form owing to defects in fullerene molecules, which fulfill the role of reactive centers [111]. Further investigation of our free jet must provide the information on existing reactive species and give an idea of polymerization mechanism.

Table 2. Features observed in the Raman spectra of Carbon deposited on Si substrates.

\begin{tabular}{ccc}
\hline Peak & Vibrational Assignment & Reference \\
\hline $1080 \mathrm{~cm}^{-1}$ & $\mathrm{C}-\mathrm{H}$ bend $+\mathrm{C}-\mathrm{C}$ stretch & {$[112,113]$} \\
$1175 \mathrm{~cm}^{-1}$ & $\mathrm{C}-\mathrm{H}$ bend or $\mathrm{E}_{1}^{\prime \prime}(\mathrm{C} 70)$ or $\mathrm{H}_{\mathrm{g}}(5)(\mathrm{C} 60)$ & {$[98,113,114]$} \\
$1232 \mathrm{~cm}^{-1}$ & $\mathrm{~A}_{1}^{\prime}(\mathrm{C} 70)$ & {$[96]$} \\
$1320 \mathrm{~cm}^{-1}$ & $\mathrm{G}_{\mathrm{u}}(5)(\mathrm{C} 60)$ or $\mathrm{E}_{1}^{\prime}(\mathrm{C} 70)$ or the $\mathrm{D}-$ band & {$[82,97]$} \\
$1350 \mathrm{~cm}^{-1}$ & $\mathrm{~T}_{2 \mathrm{~g}}(4)(\mathrm{C} 60)$ or $\mathrm{E}_{2}^{\prime}(\mathrm{C} 70)$ & {$[97]$} \\
\hline
\end{tabular}


Table 2. Cont.

\begin{tabular}{ccc}
\hline Peak & Vibrational Assignment & Reference \\
\hline $1360 \mathrm{~cm}^{-1}$ & $\mathrm{D}$ band related $\mathrm{sp}^{2}-\mathrm{C}$ & {$[114]$} \\
$1370 \mathrm{~cm}^{-1}$ & $\mathrm{H}_{\mathrm{g}}(7)(\mathrm{C} 60)$ or $\mathrm{E}_{2}^{\prime}(\mathrm{C} 70)$ & {$[97]$} \\
$1414 \mathrm{~cm}^{-1}$ & $\mathrm{H}_{\mathrm{u}}(6)(\mathrm{C} 60){\text { or } \mathrm{E}_{1}^{\prime}(\mathrm{C} 70)}^{\prime}$ & {$[97]$} \\
$1439 \mathrm{~cm}^{-1}$ & $\mathrm{~T}_{1 \mathrm{u}}(4)(\mathrm{C} 60)$ or $\mathrm{E}_{1}^{\prime}(\mathrm{C} 70)$ & {$[96,97]$} \\
$1449 \mathrm{~cm}^{-1}$ & $\mathrm{H}_{\mathrm{g}}(7)(\mathrm{C} 60)$ or $\mathrm{E}_{1}^{\prime \prime}(\mathrm{C} 70)$ & {$[97]$} \\
$1560 \mathrm{~cm}^{-1}$ & $\mathrm{H}_{\mathrm{u}}(7)(\mathrm{C} 60)$ or the G band & {$[115,116]$} \\
\hline
\end{tabular}

\section{Conclusions}

In this work, a novel free jet system was evaluated in ambient conditions. The optimized MF-power generation could produce excited species in hydrogen-containing gas mixtures making them chemically active. Using $10 \%$ vol. $\mathrm{H}_{2} / \mathrm{N}_{2}$ forming gas, $20 \mathrm{~nm}$ GO-films were successfully reduced within a processing time of $2 \mathrm{~s}$ according to XPS and Raman analyses. The rGO films thus obtained were comparable in quality with the rGO films reduced in RF hydrogen plasma under optimized and established conditions. A longer free jet treatment resulted in further deoxygenation with the appearance of a strong Raman peak at $1447 \mathrm{~cm}^{-1}$, which was attributed to trans-polyacetylene $\left(-\mathrm{CH}_{2}\right)$ chains. The appearance of such chains reflects the breaking of the honeycomb carbon network in GO. A closer analytical look into the free-jet constituents and their energies is planned to control and improve the process, e.g., to not damage the GO surface at longer treatment.

By introducing the acetylene admixture into the forming gas, we realized the deposition of carbon films by our free jet system. Multiple activations of the depositing surface via dynamic oscillating treatment resulted according to Raman spectroscopy analysis in a formation of the fullerene C70-like matter. SEM revealed the presence of aggregated spherical nanoparticles from a few-10s to over a few-100s of nm. These particles resembled the onion-like nanostructure, which contains fullerene-like particles, as reported in the literature. The carbon films deposited on (111)-textured Ag surface had nano needle-like structures (a few 10s nm in diameter and a few 100s nm long). Raman spectroscopy also revealed the presence of graphitic carbon (estimated crystallite size, $\mathrm{L}_{\mathrm{a}} \approx 9-12 \mathrm{~nm}$ ). The number of nanocrystalline carbon needles reduced with increasing deposition time and nozzle-to-substrate distance.

The preliminary results based on our free jet system demonstrated unique simplicity in the synthesis of various carbon nanostructures at atmospheric pressure. The presented method opens an inexpensive, scalable, and entirely vacuum-free way to produce rGO coatings. The low gas temperature of the jet enables using any sensitive substrates including flexible ones. Furthermore, we believe that a much faster (seconds vs. tens of minutes) and vacuum-free reduction process has more potential to be realized on an industrial scale, e.g., in reel-to-reel production concepts. A deep scientific understanding of the excitation processes occurring in gases coupled electrically in this way is of imperative importance.

Supplementary Materials: The following are available online at https: / www.mdpi.com/article/ 10.3390/c7040071/s1: Figure S1: XRD pattern and pole-figure of the ZnO/Ag substrate, Figure S2: Photographs of the APPJ used in this work, Figure S3: Raman spectra of GO and rGO prepared with APPJ, Figure S4: XPS survey spectra for Si, GO, and various rGO, Figure S5: Wide Raman spectra of carbon deposited on $\mathrm{ZnO} / \mathrm{Ag}$ substrates. Figures S6 and S7: SEM images of carbon deposited on $\mathrm{ZnO} / \mathrm{Ag}$ substrates, Figure S8: SEM images of carbon deposited on Si substrates, Table S1: Parameters from Raman spectroscopy of GO and various rGO, Table S2: Parameters from Raman spectroscopy of various carbon deposited on $\mathrm{ZnO} / \mathrm{Ag}$ substrates.

Author Contributions: The conceptualization, organization, supervision, XRD measurements, review, and editing of the draft, R.M.; development of the special APPJ system, U.H.; experimental realization, analyses of data, and writing of the original draft, S.H.B.V.K.; Raman measurements and support with data analyses, J.I.-J.; XPS measurements and support with data analyses, N.M.; synthesis of GO and rGO powders and preparation of their stable suspensions, K.K., RF-plasma 
treatments in hydrogen, M.Z.; SEM and EDX analyses, U.G.; scientific and administrative support on GO and rGO precursors, L.L.; project administration and funding acquisition, B.S. and R.S. All authors have read and agreed to the published version of the manuscript.

Funding: The authors acknowledge support from the German Federal Ministry for Economic Affairs and Energy (BMWi) in the framework of the project "speedCIGS" (grant no. 0324095H) and the German Federal Ministry of Education and Research (BMBF) in the framework of the project "Catlab" (grant no. 03EW0015A/B). The authors also acknowledge the support from the German Research Foundation and the Open Access Publication Fund of TU Berlin. Josefa Ibaceta-Jaña acknowledges the financial support provided by the Scholarship Becas Chile-DAAD 2017/91645541.

Data Availability Statement: The data presented in this study are available on request from the corresponding author.

Acknowledgments: We sincerely thank Ansgar Jahn for the first basic technical support provided by RAANTEC GmbH \& Co. KG (Borgholzhausen, Germany). We gratefully acknowledge our colleagues Alexander Steigert from the Institute for Nanospectroscopy, HZB (Berlin, Germany) who provided the $i-\mathrm{ZnO}$ films on the glass and Katja Mayer-Stillrich and Manuel Hartig from PVcomB, HZB (Berlin, Germany) for the deposition of Ag-films. We thank Markus R. Wagner for providing access and support for the Raman spectroscopy measurements. The experimenters thank Iver Lauermann from PVcomB, HZB (Berlin, Germany) for providing chemical infrastructure. In a few cases, Christoph Fahrenson from ZELMi, TU Berlin (Germany) made SEM images.

Conflicts of Interest: The authors declare no conflict of interest. The funders had no role in the design of the study; in the collection, analyses, or interpretation of data; in the writing of the manuscript, or in the decision to publish the results.

\section{References}

1. Adamovich, I.; Baalrud, S.D.; Bogaerts, A.; Bruggeman, P.J.; Cappelli, M.; Colombo, V.; Czarnetzki, U.; Ebert, U.; Eden, J.G.; Favia, P.; et al. The 2017 Plasma Roadmap: Low temperature plasma science and technology. J. Phys. D Appl. Phys. 2017, 50, 323001. [CrossRef]

2. Penkov, O.V.; Khadem, M.; Lim, W.-S.; Kim, D.-E. A review of recent applications of atmospheric pressure plasma jets for materials processing. J. Coat. Technol. Res. 2015, 12, 225-235. [CrossRef]

3. Belmonte, T.; Henrion, G.; Gries, T. Nonequilibrium Atmospheric Plasma Deposition. J. Therm. Spray Technol. 2011, 20, 744-759. [CrossRef]

4. Di, L.; Zhang, J.; Zhang, X. A review on the recent progress, challenges, and perspectives of atmospheric-pressure cold plasma for preparation of supported metal catalysts. Plasma Process. Polym. 2018, 15, 1700234. [CrossRef]

5. Braný, D.; Dvorská, D.; Halašová, E.; Škovierová, H. Cold atmospheric plasma: A powerful tool for modern medicine. Int. J. Mol. Sci. 2020, 21, 2932. [CrossRef] [PubMed]

6. Eliasson, B.; Kogelschatz, U. Nonequilibrium Volume Plasma Chemical Processing. IEEE Trans. Plasma Sci. 1991, 19, 1063-1077. [CrossRef]

7. Schütze, A.; Jeong, J.Y.; Babayan, S.E.; Park, J.; Selwyn, G.S.; Hicks, R.F. The atmospheric-pressure plasma jet: A review and comparison to other plasma sources. IEEE Trans. Plasma Sci. 1998, 26, 1685-1694. [CrossRef]

8. Conrads, H.; Schmidt, M. Plasma generation and plasma sources. Plasma Sources Sci. Technol. 2000, 9, 441-454. [CrossRef]

9. Merche, D.; Vandencasteele, N.; Reniers, F. Atmospheric plasmas for thin film deposition: A critical review. Thin Solid Film. 2012, 520, 4219-4236. [CrossRef]

10. Bogaerts, A.; Neyts, E.; Gijbels, R.; Van der Mullen, J. Gas discharge plasmas and their applications. Spectrochim. Acta Part B At Spectrosc. 2002, 57, 609-658. [CrossRef]

11. Tanaka, H.; Ishikawa, K.; Mizuno, M.; Toyokuni, S.; Kajiyama, H.; Kikkawa, F.; Metelmann, H.-R.; Hori, M. State of the art in medical applications using non-thermal atmospheric pressure plasma. Rev. Mod. Plasma Phys. 2017, 1, 3. [CrossRef]

12. Lu, X.; Laroussi, M.; Puech, V. On atmospheric-pressure non-equilibrium plasma jets and plasma bullets. Plasma Sources Sci. Technol. 2012, 21, 034005. [CrossRef]

13. Winter, J.; Brandenburg, R.; Weltmann, K.-D. Atmospheric pressure plasma jets: An overview of devices and new directions. Plasma Sources Sci. Technol. 2015, 24, 064001. [CrossRef]

14. Lu, X.; Naidis, G.V.; Laroussi, M.; Ostrikov, K. Guided ionization waves: Theory and experiments. Phys. Rep. 2014, 540, 123-166. [CrossRef]

15. De Geyter, N.; Morent, R. Cold plasma surface modification of biodegradable polymer biomaterials. In Biomaterials for Bone Regeneration. Novel Techniques and Applications; Woodhead Publishing: Sawston, UK, 2014; pp. 202-224.

16. Alotaibi, F.; Tung, T.T.; Nine, M.J.; Kabiri, S.; Moussa, M.; Tran, D.N.H.; Losic, D. Scanning atmospheric plasma for ultrafast reduction of graphene oxide and fabrication of highly conductive graphene films and patterns. Carbon 2018, 127, 113-121. [CrossRef] 
17. Chemin, J.-B.; Bulou, S.; Baba, K.; Fontaine, C.; Sindzingre, T.; Boscher, N.D.; Choquet, P. Transparent anti-fogging and selfcleaning $\mathrm{TiO}_{2} / \mathrm{SiO}_{2}$ thin films on polymer substrates using atmospheric plasma. Sci. Rep. 2018, 8, 9603. [CrossRef]

18. Nie, Q.; Cao, Z.; Ren, C.S.; Wang, D.Z.; Kong, M.G. A two-dimensional cold atmospheric plasma jet array for uniform treatment of large-area surfaces for plasma medicine. New J. Phys. 2009, 11, 115015. [CrossRef]

19. Qian, C.; Fang, Z.; Yang, J.; Kang, M. Investigation on Atmospheric Pressure Plasma Jet Array in Ar. IEEE Trans. Plasma Sci. 2014, 42, 2438-2439. [CrossRef]

20. Mostofizadeh, A.; Li, Y.; Song, B.; Huang, Y. Synthesis, Properties, and Applications of Low-Dimensional Carbon-Related Nanomaterials. J. Nanomater. 2011, 2011, 685081. [CrossRef]

21. Gonzalez-Aguilar, J.; Moreno, M.; Fulcheri, L. Carbon nanostructures production by gas-phase plasma processes at atmospheric pressure. J. Phys. D Appl. Phys. 2007, 40, 2361-2374. [CrossRef]

22. Vollath, D. Plasma synthesis of nanopowders. J. Nanopart. Res. 2008, 10, 39-57. [CrossRef]

23. Sun, X.; Bao, J.; Li, K.; Argyle, M.D.; Tan, G.; Adidharma, H.; Zhang, K.; Fan, M.; Ning, P. Advance in Using Plasma Technology for Modification or Fabrication of Carbon-Based Materials and Their Applications in Environmental, Material, and Energy Fields. Adv. Funct. Mater. 2020, 31, 2006287. [CrossRef]

24. Antonova, I.V.; Shavelkina, M.B.; Ivanov, A.I.; Soots, R.A.; Ivanov, P.P.; Bocharov, A.N. Graphene Flakes for Electronic Applications: DC Plasma Jet-Assisted Synthesis. Nanomaterials 2020, 10, 2050. [CrossRef] [PubMed]

25. Kong, W.; Kum, H.; Bae, S.H.; Shim, J.; Kim, H.; Kong, L.; Meng, Y.; Wang, K.; Kim, C.; Kim, J. Path towards graphene commercialization from lab to market. Nat. Nanotechnol. 2019, 14, 927-938. [CrossRef]

26. Vinoth Kumar, S.H.B.; Muydinov, R.; Szyszka, B. Plasma assisted reduction of graphene oxide films. Nanomaterials 2021, 11, 382. [CrossRef]

27. Dato, A.; Radmilovic, V.; Lee, Z.; Phillips, J.; Frenklach, M. Substrate-free gas-phase synthesis of graphene sheets. Nano Lett. 2008, 8, 2012-2016. [CrossRef]

28. Tatarova, E.; Henriques, J.; Luhrs, C.C.; Dias, A.; Phillips, J.; Abrashev, M.V.; Ferreira, C.M. Microwave plasma based single step method for free standing graphene synthesis at atmospheric conditions. Appl. Phys. Lett. 2013, 103, 134101. [CrossRef]

29. Dato, A. Graphene synthesized in atmospheric plasmas-A review. J. Mater. Res. 2019, 34, 214. [CrossRef]

30. Toman, J.; Jasek, O.; Snirer, M.; Kudrle, V.; Jurmanova, J. On the interplay between plasma discharge instability and formation of free-standing graphene nanosheets in a dual-channel microwave plasma torch at atmospheric pressure. J. Phys. D Appl. Phys. 2019, 52, 265205. [CrossRef]

31. Jašek, O.; Toman, J.; Jurmanová, J.; Šnírer, M.; Kudrle, V.; Buršíková, V. Study of graphene layer growth on dielectric substrate in microwave plasma torch at atmospheric pressure. Diam. Relat. Mater. 2020, 105, 107798. [CrossRef]

32. Shavelkina, M.B.; Ivanov, P.P.; Bocharov, A.N.; Amirov, R.K. 1D modeling of the equilibrium plasma flow in the scope of direct current plasma torch assisted graphene synthesis. J. Phys. D Appl. Phys. 2019, 52, 495202. [CrossRef]

33. Shavelkina, M.B.; Amirov, R.K.; Kavyrshin, D.I.; Yusupov, D.I. Plasma Jet-Assisted Synthesis of Graphene Using a DC Plasma Torch. Plasma Phys. Rep. 2019, 45, 1080-1086. [CrossRef]

34. Shavelkina, M.; Ivanov, P.; Bocharov, A.; Amirov, R. Distinctive Features of Graphene Synthesized in a Plasma Jet Created by a DC Plasma Torch. Materials 2020, 13, 1728. [CrossRef] [PubMed]

35. Hummers, W.S.; Offeman, R.E. Preparation of Graphitic Oxide. J. Am. Chem. Soc. 1958, 80, 1339. [CrossRef]

36. Nasiłowska, B.; Bogdanowicz, Z.; Hińcza, K.; Mierczyk, Z.; Góźdź, S.; Djas, M.; Kowiorski, K.; Bombalska, A.; Kowalik, A. Graphene oxide aerosol deposition and its influence on cancer cells. Preliminary results. Materials 2020, 13, 4464. [CrossRef]

37. Chlanda, A.; Kowiorski, K.; Małek, M.; Kijeńska-Gawrońska, E.; Bil, M.; Djas, M.; Strachowski, T.; Swieszkowski, W.; Lipińska, L. Morphology and Chemical Purity of Water Suspension of Graphene Oxide FLAKES Aged for 14 Months in Ambient Conditions. A Preliminary Study. Materials 2021, 14, 4108. [CrossRef]

38. Rohde, M.; Zelt, M.; Gabriel, O.; Neubert, S.; Kirner, S.; Severin, D.; Stolley, T.; Rau, B.; Stannowski, B.; Schlatmann, R. Plasma enhanced chemical vapor deposition process optimization for thin film silicon tandem junction solar cells. Thin Solid Film. 2014, 558, 337-343. [CrossRef]

39. Muydinov, R.; Ruske, F.; Neubert, S.; Steigert, A.; Klaus, M.; Selve, S.; Köppel, G.; Szyszka, B. Combination of nitrogen mediated crystallisation with post-deposition annealing-Towards ultra-thin ZnO:Al contacts. Thin Solid Film. 2015, 589, 750-754. [CrossRef]

40. Arbab, M. The base layer effect on the d.c. conductivity and structure of direct current magnetron sputtered thin films of silver. Thin Solid Film. 2001, 381, 15-21. [CrossRef]

41. Lauermann, I.; Steigert, A. CISSY: A station for preparation and surface/interface analysis of thin film materials and devices. J. Large-Scale Res. Facil. JLSRF 2016, 2, A67. [CrossRef]

42. Díez-Betriu, X.; Álvarez-García, S.; Botas, C.; Álvarez, P.; Sánchez-Marcos, J.; Prieto, C.; Menéndez, R.; de Andrés, A. Raman spectroscopy for the study of reduction mechanisms and optimization of conductivity in graphene oxide thin films. J. Mater. Chem. C 2013, 1, 6905. [CrossRef]

43. Claramunt, S.; Varea, A.; López-Díaz, D.; Velázquez, M.M.; Cornet, A.; Cirera, A. The importance of interbands on the interpretation of the raman spectrum of graphene oxide. J. Phys. Chem. C 2015, 119, 10123-10129. [CrossRef]

44. Sadezky, A.; Muckenhuber, H.; Grothe, H.; Niessner, R.; Pöschl, U. Raman microspectroscopy of soot and related carbonaceous materials: Spectral analysis and structural information. Carbon 2005, 43, 1731-1742. [CrossRef] 
45. Zhao, X.; Ando, Y. Raman Spectra and X-Ray Diffraction Patterns of Carbon Nanotubes Prepared by Hydrogen Arc Discharge. Jpn. J. Appl. Phys. 1998, 37, 4846-4849. [CrossRef]

46. Kudin, K.N.; Ozbas, B.; Schniepp, H.C.; Prud'Homme, R.K.; Aksay, I.A.; Car, R. Raman Spectra of Graphite Oxide and Functionalized Graphene Sheets. Nano Lett. 2008, 8, 36-41. [CrossRef]

47. Nemanich, R.J.; Solin, S.A. First- and second-order Raman scattering from finite-size crystals of graphite. Phys. Rev. B 1979, 20, 392-401. [CrossRef]

48. Vollebregt, S.; Ishihara, R.; Tichelaar, F.D.; Hou, Y.; Beenakker, C.I.M. Influence of the growth temperature on the first and second-order Raman band ratios and widths of carbon nanotubes and fibers. Carbon 2012, 50, 3542-3554. [CrossRef]

49. Goodman, P.A.; Li, H.; Gao, Y.; Lu, Y.F.; Stenger-Smith, J.D.; Redepenning, J. Preparation and characterization of high surface area, high porosity carbon monoliths from pyrolyzed bovine bone and their performance as supercapacitor electrodes. Carbon 2013, 55, 291-298. [CrossRef]

50. Saito, R.; Hofmann, M.; Dresselhaus, G.; Jorio, A.; Dresselhaus, M.S. Raman spectroscopy of graphene and carbon nanotubes. Adv. Phys. 2011, 60, 413-550. [CrossRef]

51. Liu, Y.; Zhou, J.; Zhang, X.; Liu, Z.; Wan, X.; Tian, J.; Wang, T.; Chen, Y. Synthesis, characterization and optical limiting property of covalently oligothiophene-functionalized graphene material. Carbon 2009, 47, 3113-3121. [CrossRef]

52. Jenrette, E.; Pradhan, S.K.; Rutherford, G.; Flowers, J.; Ha, D.; Pradhan, A.K. Quantum-dot-conjugated graphene oxide as an optical tool for biosensor. Opt. Express 2015, 23, 25017. [CrossRef] [PubMed]

53. Chaturvedi, D.; Balaji, S.; Bn, V.; Ariese, F.; Umapathy, S.; Rangarajan, A. Different Phases of Breast Cancer Cells: Raman Study of Immortalized, Transformed, and Invasive Cells. Biosensors 2016, 6, 57. [CrossRef]

54. Baibarac, M.; Lapkowski, M.; Pron, A.; Lefrant, S.; Baltog, I. SERS spectra of poly(3-hexylthiophene) in oxidized and unoxidized states. J. Raman Spectrosc. 1998, 29, 825-832. [CrossRef]

55. Nyamekye, C.K.A.; Bobbitt, J.M.; Zhu, Q.; Smith, E.A. The evolution of total internal reflection Raman spectroscopy for the chemical characterization of thin films and interfaces. Anal. Bioanal. Chem. 2020, 412, 6009-6022. [CrossRef]

56. Ferrari, A.C.; Robertson, J. Origin of the $1150-\mathrm{cm}^{-1}$ Raman mode in nanocrystalline diamond. Phys. Rev. B 2001, 63, 121405. [CrossRef]

57. Wu, J.B.; Lin, M.L.; Cong, X.; Liu, H.N.; Tan, P.H. Raman spectroscopy of graphene-based materials and its applications in related devices. Chem. Soc. Rev. 2018, 47, 1822-1873. [CrossRef] [PubMed]

58. Krishnamoorthy, K.; Veerapandian, M.; Yun, K.; Kim, S.-J. The chemical and structural analysis of graphene oxide with different degrees of oxidation. Carbon 2013, 53, 38-49. [CrossRef]

59. Ma, B.; Rodriguez, R.D.; Ruban, A.; Pavlov, S.; Sheremet, E. The correlation between electrical conductivity and second-order Raman modes of laser-reduced graphene oxide. Phys. Chem. Chem. Phys. 2019, 21, 10125-10134. [CrossRef]

60. Ganguly, A.; Sharma, S.; Papakonstantinou, P.; Hamilton, J. Probing the Thermal Deoxygenation of Graphene Oxide Using High-Resolution In Situ X-ray-Based Spectroscopies. J. Phys. Chem. C 2011, 115, 17009-17019. [CrossRef]

61. Martins Ferreira, E.H.; Moutinho, M.V.O.; Stavale, F.; Lucchese, M.M.; Capaz, R.B.; Achete, C.A.; Jorio, A. Evolution of the Raman spectra from single-, few-, and many-layer graphene with increasing disorder. Phys. Rev. B 2010, 82, 125429. [CrossRef]

62. Wei, G.; Yu, J.; Gu, M.; Tang, T.B. Dielectric relaxation and hopping conduction in reduced graphite oxide. J. Appl. Phys. 2016, 119, 224102. [CrossRef]

63. Kamedulski, P.; Truszkowski, S.; Lukaszewicz, J.P. Highly effective methods of obtaining n-doped graphene by gamma irradiation. Materials 2020, 13, 4975. [CrossRef] [PubMed]

64. Chen, X.; Wang, X.; Fang, D. A review on C1s XPS-spectra for some kinds of carbon materials. Fuller. Nanotub. Carbon Nanostruct. 2020, 28, 1048-1058. [CrossRef]

65. Ahn, M.; Liu, R.; Lee, C.; Lee, W. Designing Carbon/Oxygen Ratios of Graphene Oxide Membranes for Proton Exchange Membrane Fuel Cells. J. Nanomater. 2019, 2019, 6464713. [CrossRef]

66. Teng, C.C.; Ma, C.C.M.; Lu, C.H.; Yang, S.Y.; Lee, S.H.; Hsiao, M.C.; Yen, M.Y.; Chiou, K.C.; Lee, T.M. Thermal conductivity and structure of non-covalent functionalized graphene/epoxy composites. Carbon 2011, 49, 5107-5116. [CrossRef]

67. Sygellou, L.; Paterakis, G.; Galiotis, C.; Tasis, D. Work Function Tuning of Reduced Graphene Oxide Thin Films. J. Phys. Chem. C 2016, 120, 281-290. [CrossRef]

68. Tatarova, E.; Dias, A.; Henriques, J.; Abrashev, M.; Bundaleska, N.; Kovacevic, E.; Bundaleski, N.; Cvelbar, U.; Valcheva, E.; Arnaudov, B.; et al. Towards large-scale in free-standing graphene and N-graphene sheets. Sci. Rep. 2017, 7, 10175. [CrossRef]

69. Chowdhury, F.A.; Hossain, M.A.; Uchida, K.; Tamura, T.; Sugawa, K.; Mochida, T.; Otsuki, J.; Mohiuddin, T.; Boby, M.A.; Alam, M.S. Graphene oxide/carbon nanoparticle thin film based IR detector: Surface properties and device characterization. AIP Adv. 2015, 5, 107228. [CrossRef]

70. Marrani, A.G.; Motta, A.; Palmieri, V.; Perini, G.; Papi, M.; Dalchiele, E.A.; Schrebler, R.; Zanoni, R. A comparative experimental and theoretical study of the mechanism of graphene oxide mild reduction by ascorbic acid and $\mathrm{N}$-acetyl cysteine for biomedical applications. Mater. Adv. 2020, 1, 2745-2754. [CrossRef]

71. Tuinstra, F.; Koenig, J.L. Raman Spectrum of Graphite. J. Chem. Phys. 1970, 53, 1126-1130. [CrossRef]

72. Cançado, L.G.; Takai, K.; Enoki, T.; Endo, M.; Kim, Y.A.; Mizusaki, H.; Jorio, A.; Coelho, L.N.; Magalhães-Paniago, R.; Pimenta, M.A. General equation for the determination of the crystallite size La of nanographite by Raman spectroscopy. Appl. Phys. Lett. 2006, 88, 163106. [CrossRef] 
73. Puech, P.; Kandara, M.; Paredes, G.; Moulin, L.; Weiss-Hortala, E.; Kundu, A.; Ratel-Ramond, N.; Plewa, J.-M.; Pellenq, R.; Monthioux, M. Analyzing the Raman Spectra of Graphenic Carbon Materials from Kerogens to Nanotubes: What Type of Information Can Be Extracted from Defect Bands? C J. Carbon Res. 2019, 5, 69. [CrossRef]

74. Kalache, B.; Novikova, T.; Fontcuberta i Morral, A.; Roca i Cabarrocas, P.; Morscheidt, W.; Hassouni, K. Investigation of coupling between chemistry and discharge dynamics in radio frequency hydrogen plasmas in the Torr regime. J. Phys. D Appl. Phys. 2004 37, 1765-1773. [CrossRef]

75. Debrabandere, D.; Eynde, X.V.; Reniers, F. Effects of hydrogen addition in nitrogen atmospheric pressure plasma on its optical and electrical properties and silicon-based deposits compositions. J. Phys. Conf. Ser. 2011, 275, 012011. [CrossRef]

76. Ilik, E.; Durmuş, Ç.; Akan, T. Optical Investigations of N2 Atmospheric Pressure Plasma Jets. Adıyaman Univ. J. Sci. 2020, 10, 326-338. [CrossRef]

77. Parashar, U.K.; Bhandari, S.; Srivastava, R.K.; Jariwala, D.; Srivastava, A. Single step synthesis of graphene nanoribbons by catalyst particle size dependent cutting of multiwalled carbon nanotubes. Nanoscale 2011, 3, 3876. [CrossRef] [PubMed]

78. Niu, T.; Zhou, M.; Zhang, J.; Feng, Y.; Chen, W. Growth Intermediates for CVD Graphene on Cu(111): Carbon Clusters and Defective Graphene. J. Am. Chem. Soc. 2013, 135, 8409-8414. [CrossRef] [PubMed]

79. Fernandez, T.T.; Gross, S.; Arriola, A.; Privat, K.; Withford, M.J. Revisiting ultrafast laser inscribed waveguide formation in commercial alkali-free borosilicate glasses. Opt. Express 2020, 28, 10153. [CrossRef] [PubMed]

80. Montenegro, D.N.; Hortelano, V.; Martínez, O.; Martínez-Tomas, M.C.; Sallet, V.; Muñoz-Sanjosé, V.; Jiménez, J. Non-radiative recombination centres in catalyst-free $\mathrm{ZnO}$ nanorods grown by atmospheric-metal organic chemical vapour deposition. J. Phys. $D$ Appl. Phys. 2013, 46, 235302. [CrossRef]

81. Martina, I.; Wiesinger, R.; Schreiner, M.; Martína, I.; Wiesinger, R.; Jembrih-Simbürger, D.; Schreiner, M.; Martina, I.; Wiesinger, R.; Schreiner, M. Micro-Raman Characterisation of Silver Corrosion Products: Instrumental Set Up and Reference Database. $e-$ Preserv. Sci. 2012, 9, 1-8.

82. Scheibe, H.-J.; Drescher, D.; Alers, P. Raman characterization of amorphous carbon films. Fresenius J. Anal. Chem. 1995, 353, 695-697. [CrossRef]

83. Jorio, A.; Saito, R. Raman spectroscopy for carbon nanotube applications. J. Appl. Phys. 2021, 129, 021102. [CrossRef]

84. Mohiuddin, T.M.G.; Lombardo, A.; Nair, R.R.; Bonetti, A.; Savini, G.; Jalil, R.; Bonini, N.; Basko, D.M.; Galiotis, C.; Marzari, N.; et al. Uniaxial strain in graphene by Raman spectroscopy: Gpeak splitting, Grüneisen parameters, and sample orientation. Phys. Rev. B 2009, 79, 205433. [CrossRef]

85. Mikael, S.; Seo, J.-H.; Javadi, A.; Gong, S.; Ma, Z. Wrinkled bilayer graphene with wafer scale mechanical strain. Appl. Phys. Lett. 2016, 108, 183101. [CrossRef]

86. Podila, R.; Rao, R.; Tsuchikawa, R.; Ishigami, M.; Rao, A.M. Raman Spectroscopy of Folded and Scrolled Graphene. ACS Nano 2012, 6, 5784-5790. [CrossRef] [PubMed]

87. Vidano, R.P.; Fischbach, D.B.; Willis, L.J.; Loehr, T.M. Observation of Raman band shifting with excitation wavelength for carbons and graphites. Solid State Commun. 1981, 39, 341-344. [CrossRef]

88. Ferrari, A.C.; Meyer, J.C.; Scardaci, V.; Casiraghi, C.; Lazzeri, M.; Mauri, F.; Piscanec, S.; Jiang, D.; Novoselov, K.S.; Roth, S.; et al. Raman Spectrum of Graphene and Graphene Layers. Phys. Rev. Lett. 2006, 97, 187401. [CrossRef]

89. Ferrari, A.C. Raman spectroscopy of graphene and graphite: Disorder, electron-phonon coupling, doping and nonadiabatic effects. Solid State Commun. 2007, 143, 47-57. [CrossRef]

90. Couzi, M.; Bruneel, J.-L.; Talaga, D.; Bokobza, L. A multi wavelength Raman scattering study of defective graphitic carbon materials: The first order Raman spectra revisited. Carbon 2016, 107, 388-394. [CrossRef]

91. Pawlyta, M.; Rouzaud, J.N.; Duber, S. Raman microspectroscopy characterization of carbon blacks: Spectral analysis and structural information. Carbon 2015, 84, 479-490. [CrossRef]

92. Niwase, K.; Tanaka, T.; Kakimoto, Y.; Ishihara, K.N.; Shingu, P.H. Raman Spectra of Graphite and Diamond Mechanically Milled with Agate or Stainless Steel Ball-Mill. Mater. Trans. JIM 1995, 36, 282-288. [CrossRef]

93. Herziger, F.; Tyborski, C.; Ochedowski, O.; Schleberger, M.; Maultzsch, J. Double-resonant la phonon scattering in defective graphene and carbon nanotubes. Phys. Rev. B 2014, 90, 245431. [CrossRef]

94. Czamara, K.; Majzner, K.; Pacia, M.Z.; Kochan, K.; Kaczor, A.; Baranska, M. Raman spectroscopy of lipids: A review. J. Raman Spectrosc. 2015, 46, 4-20. [CrossRef]

95. Kochan, K.; Peng, H.; Gwee, E.S.H.; Izgorodina, E.; Haritos, V.; Wood, B.R. Raman spectroscopy as a tool for tracking cyclopropane fatty acids in genetically engineered Saccharomyces cerevisiae. Analyst 2019, 144, 901-912. [CrossRef] [PubMed]

96. Meilunas, R.; Chang, R.P.H.; Liu, S.; Jensen, M.; Kappes, M.M. Infrared and Raman spectra of C 60 and C 70 solid films at room temperature. J. Appl. Phys. 1991, 70, 5128-5130. [CrossRef]

97. Schettino, V.; Pagliai, M.; Cardini, G. The Infrared and Raman Spectra of Fullerene C 70. DFT Calculations and Correlation with C 60. J. Phys. Chem. A 2002, 106, 1815-1823. [CrossRef]

98. Dychalska, A.; Popielarski, P.; Franków, W.; Fabisiak, K.; Paprocki, K.; Szybowicz, M. Study of CVD diamond layers with amorphous carbon admixture by Raman scattering spectroscopy. Mater. Sci. 2015, 33, 799-805. [CrossRef]

99. Marcinauskas, L.; Černauskas, M.; Milieška, M.; Reso, D. The effect of hydrogen addition in argon-acetylene plasma on the structure of amorphous carbon films. J. Non-Cryst. Solids 2017, 466-467, 1-7. [CrossRef] 
100. Birrell, J.; Gerbi, J.E.; Auciello, O.; Gibson, J.M.; Johnson, J.; Carlisle, J.A. Interpretation of the Raman spectra of ultrananocrystalline diamond. Diam. Relat. Mater. 2005, 14, 86-92. [CrossRef]

101. Hasdeo, E.H.; Nugraha, A.R.T.; Dresselhaus, M.S.; Saito, R. Breit-Wigner-Fano line shapes in Raman spectra of graphene. Phys. Rev. B 2014, 90, 245140. [CrossRef]

102. Zhao, S.; Hong, R.; Luo, Z.; Lu, H.; Yan, B. Carbon Nanostructures Production by AC Arc Discharge Plasma Process at Atmospheric Pressure. J. Nanomater. 2011, 2011, 1-6. [CrossRef]

103. Chen, L.S.; Wang, C.J. Low Temperature Large Scale CVD Synthesis of Nano Onion-Like Fullerenes. Adv. Mater. Res. 2012, 490-495, 3211-3214. [CrossRef]

104. Yang, Y.; Liu, X.; Guo, X.; Wen, H.; Xu, B. Synthesis of nano onion-like fullerenes by chemical vapor deposition using an iron catalyst supported on sodium chloride. J. Nanopart. Res. 2011, 13, 1979-1986. [CrossRef]

105. Du, A.B.; Liu, X.G.; Fu, D.J.; Han, P.D.; Xu, B.S. Onion-like fullerenes synthesis from coal. Fuel 2007, 86, 294-298. [CrossRef]

106. Kaltchev, M.; Stacchiola, D.; Molero, H.; Wu, G.; Blumenfeld, A.; Tysoe, W.T. On the reaction pathway for the formation of benzene from acetylene catalyzed by palladium. Catal. Lett. 1999, 60, 11-14. [CrossRef]

107. Broere, D.L.J.; Ruijter, E. Recent advances in transition-metal-catalyzed [2+2+2]-cyclo(co) trimerization reactions. Synthesis 2012, 44, 2639-2672. [CrossRef]

108. Sakurai, H.; Nakadaira, Y.; Hosomi, A.; Eriyama, Y.; Hirama, K.; Kabuto, C. Intramolecular cyclotrimerization of macrocylic and acyclic triynes with Group 6 metal carbonyls. The formation of fulvene and benzene. J. Am. Chem. Soc. 1984, 106, 8315-8316. [CrossRef]

109. Shapiro, I.; Weiss, H.G. Cyclization of acetylene-d2 to benzene-d6. J. Am. Chem. Soc. 1957, 79, 3294. [CrossRef]

110. Cota-Sanchez, G.; Soucy, G.; Huczko, A.; Beauvais, J.; Drouin, D. Effect of Iron Catalyst on the Synthesis of Fullerenes and Carbon Nanotubes in Induction Plasma. J. Phys. Chem. B 2004, 108, 19210-19217. [CrossRef]

111. Berezkin, V.I. Fullerenes as nuclei of carbon black particles. Phys. Solid State 2000, 42, 580-585. [CrossRef]

112. Boyer, M.-I.; Quillard, S.; Rebourt, E.; Louarn, G.; Buisson, J.P.; Monkman, A.; Lefrant, S. Vibrational Analysis of Polyaniline: A Model Compound Approach. J. Phys. Chem. B 1998, 102, 7382-7392. [CrossRef]

113. Morávková, Z.; Šeděnková, I.; Bober, P. The First Stages of Chemical and Electrochemical Aniline Oxidation-Spectroscopic Comparative Study. Appl. Sci. 2020, 10, 2091. [CrossRef]

114. Capote, G.; Mastrapa, G.C.; Trava-Airoldi, V.J. Influence of acetylene precursor diluted with argon on the microstructure and the mechanical and tribological properties of a-C:H films deposited via the modified pulsed-DC PECVD method. Surf. Coat. Technol. 2015, 284, 145-152. [CrossRef]

115. Kuzmany, H.; Pfeiffer, R.; Hulman, M.; Kramberger, C. Raman spectroscopy of fullerenes and fullerene-nanotube composites. Philos. Trans. R. Soc. Lond. Ser. A Math. Phys. Eng. Sci. 2004, 362, 2375-2406. [CrossRef]

116. Frezzotti, M.L. Diamond growth from organic compounds in hydrous fluids deep within the Earth. Nat. Commun. 2019, 10, 4952. [CrossRef] [PubMed] 